\title{
The Risk Society: \\ Towards a new modernity
}

Authored by Beck, Ulrich. Barcelona, Paidos. 2006.

pp. 393. ISBN 84-493-1892-0

\section{Reviewed by Maximiliano E. Korstanje \\ Department of Economics \\ University of Palermo, Argentina maxikorstanje@hotmail.com}

The present review discusses one of the pioneer projects authored by Ulrich Beck, regarding risk perception issues, which was originally titled Risikogesellshaft, Auf dem weg in eine andere Moderne or in English The society of risk, towards a new modernity. This review is part of a broader project related to a Social Psychology doctoral thesis on fears of travelling in urban circumstances.

Terrorist attacks, SARS and virus disseminations, natural disasters and other catastrophes will jeopardize the enhancement of tourism throughout the world in future decades. Recent research in fields relating to tourism has thus devoted considerable attention to risk perception theory and the role of risk perception in decision-making when developing the image of a tourist destination. These studies are, however, occasionally superficial, contradictory and troublesome. Experts, planners and scholars nonetheless agree that sustainable policies in tourist security are needed. To gain further understanding about risk perception issues, we strongly believe it is necessary to review the contributions of Beck on this matter.

Even though this work was originally published in 1986, Beck is regarded as the authority of current concerns regarding the relationship between modernity and hazards. At a time when the effects of capitalism on the environment are under debate, this book presents an historical analogy for the purpose of reconsidering a classical conceptualization of progress and development.

In his introductory chapter, Beck argues that the process of modernity suffered a setback when a nuclear accident occurred in Chernobyl, Ukraine. After this tragedy, the perception of threats was radically altered. Unlike medieval travelers, who evaluated personal risks before departing, a new form of living the adventure began surfacing. It follows that global dangers are represented as collective, catastrophic and chaotic beyond the possibilities of individual reaction. To put this brutally, there is nothing one can do when a catastrophe is coming.

In such a context, Beck suggests that a shift of this magnitude is feasible in accordance with the increasing materiality and empowerment of productive forces. In this way, threats are 
implicitly derived as products of economic development. The implication of this is that sooner or later the magnitude of these threats outstrips a society's ability to respond, resulting in the system's collapse. Unlike bourgeois society, which maintained the line between poverty and richness, modern societies face a new configuration of social order. The fact is that this transformation has given birth to a new kind of society known as "The Society of Risk" where fears and risk are indiscriminately distributed to all strata of the structure.

Mass-consumption, in association with a growing sentiment of fear, has paved the way for a new spirit of capitalism. As a result, the logic of appropriation, which characterized classical mercantilism in past decades, has been replaced by its own antithesis, the logic of denial. It is not surprising that privileged groups hide collateral damage derived from non-sustainable consumption; their practices are supported thanks to the intervention of Science and Journalism. The underlying problem seems to be that duties and responsibilities are globalized at the same time that humankind jeopardizes its safety by exhausting the non-renewable natural resources and by polluting the ozone layer. Implicitly or not, this blurs the boundaries between victim and culprit. Industrialized societies are frequently involved in minor risks, of course many of them are ignored or disregarded. The gradual accumulation of these unperceived threats corresponds with other major risks that may very well jeopardize the social life. In perspective, fears emerge whenever the risks are denied. For example, popular wisdom valorizes the car as a safer mode of transport than airplanes or trains, however international statistics clearly demonstrate that the opposite is in fact true.

Beck goes on to explain that in the traditional society of class, groups configure their distinctions according to the style of consumption embodied in early socialization processes. Risks are therefore conceived as well-known, and experienced individually or internally. Nowadays, however, threats are external to the jurisdiction of people. According to journalists and authorities in the field of biology, risks not only appear to have everywhere multiplied in recent years but also seem to have eroded the cognitive sovereignty of citizens. In order to alleviate the burden caused by the perception of dangers, the market puts forward multiple solutions in the form of new products for security purposes.

Basically, Beck is concerned about the degradation of the environment because of toxic waste. Since this new form of perceiving modernity obliges countries to combine efforts for solving daunting risks, the quality of the community is being gradually transformed, and in this transformation, concepts such as equality, richness and democracy are replaced by security concerns, conflict and fears.

With such a change of mind, the idea of hiearchichal distinction as a product of personal hard work drives thinkers towards more complex symbolic constructs in which nobody feels safe. Once again, fears of downward social movement which characterized industrialism are giving way to the compulsory necessity for preventing "the worst", as a catastrophe becomes more shocking when it is unexpected than do other misfortunes such as disease or poverty. Of course, these incubated sentiments give rise to what Beck calls "The society of Fear". 
In successive chapters, Beck emphasizes that the production of risks is inversely proportional to the distribution of wealth. His main thesis is aimed at contrasting how, in modern societies, dangers are not limited to individual reactions; in part, material imbalances generated by capitalism are reinvented, thus reproducing an "Economic Drive" of the first order. In other words, even though global fears entail global responses, irregularities in the economy remain in an individual domain. This is because the meeting of human necessities is restricted, and once met they take time to be reactivated. Metaphorically speaking, the imposition of external risks in consumer minds constitutes an unlimited oil-well because it can never be satisfied.

Centered in an historical background, Beck compares the transition from feudalism in the Middle Ages with classical capitalism in the 18th and 19th centuries respectively. In brief, any economic production implies specific limitations and risks that are both ignored and symbolically manipulated and perpetuated. Whereas in the Middle Ages witchcraft, evil and demons shaped theological consciousness, it is "global risks" related to environmental contamination that shape consumer consciousness in contemporary European societies. Nevertheless, this situation is paradoxical because, from its very inception, society is condemned to disappear. It is just a question of time.

We have so far discussed and analyzed in detail the more important points of Beck's contributions. Even if his description is clear and illustrative with respect to the social effects of this phenomenon, there is a methodological contradiction in his development that should be reconsidered; namely, the unresolved questions as to whether the own society is freed from those risks that it virtually creates. In fact, why should society disappear? What is the empirical basis on which Beck sets his thesis? In addition, this book has been enriched with many rhetorical expressions that make its comprehension baffling. At any rate, reading this interesting text opens the door for a potential hypothesis which will be tested in the near future; "risk perception" looms larger in people who are employed than others such as those retired or pensioners. Thus, Millenarism in combination with economic factors would explain the reasons why public opinion claims that lives are continuously in danger despite the advances in the security technologies at their. What will be the role played by developing countries in this process? Where can we put Africa in the theory of Beck? Is his frame-work considered ethnocentric?

Rigby (1996) brought into question the cynical position of Europe with respect to Africa and the rest of the decolonized world. The strategy consists in representing tribal habits as chaotic, undeveloped, anomic and self-destructive, and thereby obscuring the actual factors that lie behind the current state of affairs. This happens for instance with the manipulation of some terms such as race or development where the West reconfigures its own stereotypes and prejudices with otherness. Through an excellent and well-grounded approach, Rigby argues that the conceptualization of race is intended to synthesize many of the cultural aspects of Africa into an explanatory variable of their own backwardness. In the 21 st century, this ethnocentric discourse has been ideologically aimed at debating the extent to which the presence of these characteristics in politics, economy and education has prevented Africans from being more civilized. Such Science has played a pivotal role in reinforcing existing racial stereotypes in 
colonized minds. Assuming race to be a natural and unquestionable matter, Science contributed to the European expansionism and legitimized European colonial policy. History has, however, shown that it is European interventions such as slavery, and not African cultural habits, that lie behind the current state of the continent. Rigby assumes that such social invention as race, modernity or development have allowed European societies to avoid taking responsibility for the consequences of their colonial activities in Africa and beyond (Rigby, 1996). Rigby thus argues that peripherical societies are placed in a subordinated position with respect to Central countries in part through their internalization of the Central countries' scientific advancement and authority.

The emphasis Beck puts on terms such as modernity is a feature of the book that remains susceptible to the above criticism, and questions of this nature merit critically discussion. Like Latin America and many of the countries in the Third World, an ethical dilemma confronts us when we analyze the case of Africa where a large part of the population is forced to live in conditions of utter poverty while an elite concentrates on their growing volume of wealth. Of course, whereas developed societies are characterized by the concentration of capital and by mass consumption, the rest of the world sees large numbers of peasants rushed into migrant labour to work in peripheral and less hospitable and fertile lands far-away from their homes. Beck neither assesses the responsibility for environmental concerns which industrialized countries lose sight of, nor for those that developing countries are likely to encounter in day-to-day situations. This gives the impression that the destiny of humankind is solely in the hands of civilized northern-hemisphere wisdom. To put this brutally, a sentiment of paternalism emphasizes that civilization is associated with a notion of progress, the ultimate expressions of which are rationalism, capitalism and industry; in other terms, the collateral environmental consequences of progress can only be resolved by societies characterized by sufficient economic maturity. However, this turn of mind has an underlying problem since it does not take into account the view of the "developing world". Once again, we are living at a time when the consequences of capitalism are being debated in all corners of the globe. Pollution, the contamination of rivers, nuclear accidents, global warming, deforestation and other issues are on the agenda of international environmental organisations. In such a context, discourse emphasizes the liability of industrialized nations in solving this glitch instead of assuming their own faults. Beck's assertion that capitalism is being replaced by a new socio-economic order may thus be applicable to the United States or Europe but it is not applicable to Africa where tribal relationships, ancient customs and oral traditions still remain. For that reason, a discourse which ignores the reality of Africa is ethnocentric and, once again, as in the 19th century, elusive. With this background in mind, it is evident that risk perception varies with time and culture depending on many factors, but almost always retains essential features related to the construction of hegemony.

\section{References}

Beck, U. (2006). The Risk Society: towards a new modernity. Barcelona, Paidos.

Rigby, P. (1996). African Images: racism and the End of Anthropology. Oxford, Berg. 